\title{
Питання психології
}

Хміляр О. Ф. доктор психологічних наук, професор, начальник кафедри суспільних наук Національного університету оборони України імені Івана Черняховського http://orcid.org/0000-0003-2693-1906

\section{ФЕЙК - ІНФОРМАЦЙНИЙ МАРКЕР ТА РЕГУЛЯТОР ПОВЕДІНКОВОЇ АКТИВНОСТІ ОСОБИСТОСТІ ВІЙСЬКОВОСЛУЖБОВЦЯ}

\begin{abstract}
Вільний доступ до отримання інформачії, інтенсивний і ииклічний ї̈ обіг призвели до масового поширення фейків, що посилюється широким використанням різноманітних масмедіа й особливо соціальних мереж. Стаття покликана розкрити роль фейкового повідомлення в структурі поведінкової активності особистості військовослужбовия, висвітлити семантичну конструкцію фейку задля привернення до нього уваги людиною, з'ясувати когнітивні упередження, щяо виступають інструментом переконання у прийнятті хибного рішення. Автором виокремлено умови, що максимізують вплив когнітивних упереджень та спонукають військовослужсбовия повірити фейковому повідомленню.
\end{abstract}

Ключові слова: фейк; повідомлення; дія; ефект; соиіальні медіа; когнітивні упередження; вплив.

Вступ. Сучасна пересічна особистість змушена щоденно споживати значну кількість інформації наділеної не завжди достовірними даними, постійно включатися у глобальну цифрову інформаційну мережу 3 метою орієнтації та вирішення поточних життєвих завдань. Втрата цієї властивості нерідко призводить до порушень соціальних функцій особистості, дестабілізує іiі життєвий простір, спричиняє порушення фізичного та психічного розвитку. Засоби масової інформації та різноманітні медійні ресурси зробили пересічну особистість заручником подій, у яких вона мимоволі починає брати участь [1].

Сучасні засоби пропаганди та дезінформації оперуючи фейковими повідомленнями «просунулись» настільки вперед, що перетворили друковану листівку в рудимент. Сьогодні важко знайти військовослужбовця у якого не було б смартфону із доступом до мережі Інтернет. За сприянням Головного управління морально-психологічного забезпечення ЗС України, у грудні 2019 року опитано 6500 військовослужбовців, щодо частоти користування соціальними мережами. За результатами дослідження встановлено, що майже $70 \%$ військовослужбовців щоденно відвідують соціальні мережі, щонайменше $44 \%$ опитаних проводять там до 2 год.; переважна більшість 3 них використовує соціальні мережі як спосіб отримання інформації про події у світі, Україні, Збройних Силах України $(65,9 \%)$, а не як канал спілкування 3 друзями $(34,1 \%)$. Щонайменше до $10 \%$ військових регулярно до своїх друзів долучають фейкові акаунти i лише 46,1\% військовослужбовців уміють розрізняти фейкові сторінки [1].

Основна небезпека Інтернет засобів масової інформації коріниться у їхній переважній не контрольованості 3 боку держави та ii правових інститутів, що робить користувача Інтернету легкодоступною цільовою аудиторією. Британський журналіст Дейвід Патрикаракос висвітлюючи події російськоукраїнської війни у 2014 році на Донбасі, й виклавши їх в подальшому у праці «Війна у 140 знаках. Як соціальні медіа змінюють конфлікти у XXI столітті», наголошує, що соціальні медіа наділили голосом безсилих і безголосих. 3 одного боку, це сприяло тому, що у світ вийшли історії, які справді мали бути почутими, але з іншого, - завдяки своїй здатності обійти традиційні медіа, вони також сприяли поширенню оманливих i фейкових повідомлень, здатних охопити безпрецедентно широку аудиторію [2, 179]. Виходячи 3 цього, розгляд фейку, як одного із інструментів інформаційної війни сьогодні як ніколи $є$ актуальним.

Мета статті спрямована на розкриття ролі фейкового повідомлення в структурі поведінкової активності особистості військовослужбовця, висвітлення семантичної конструкції фейку задля привернення уваги особистості та 3'ясування когнітивних упереджень, що виступають інструментом переконання у прийнятті хибних рішень.

$$
\text { Теоретичне підгрунтя. Одразу }
$$
зауважимо, що відрізнити неправдиву 


\section{Питання психології}

(фейкову) інформацію від правдивої досить складно. Маніпулятивний вплив на свідомість засобами 3МІ досліджує чимало науковців (Є. Доценко, С. Кара-Мурза, Г. Почепцов, О. Пригорницька, О. Рябоконь). Незважаючи щоденне зростання кількості фейків $\mathrm{y}$ інформаційному просторі, наукові дослідження, які б комплексно охопили особливості психологічного впливу фейкових повідомлень, як різновиду дезінформації, на психіку військовослужбовця, - практично відсутні. Значна частина праць, приурочених впливу фейків на поведінкову активність особистості виконана журналістами й за своїм спрямуванням носить ознайомчий характер, що в свою чергу позбавляє цього феномену наукового підгрунтя.

Сучасне інформаційне середовище стає дедалі агресивнішим. Інформаційні потоки, посилені сучасними медіа, характеризуються значною інтенсивністю та мобільністю, а інформація потрапляе до свого споживача значно швидше за його здатність іï успішно опанувати та інтегрувати у власну картину світу [3, 40]. Саме інформація на тлі застосування можливостей технічних $\mathrm{i}$ технологічних засобів стає головним воєнним потенціалом держави та «зброєю масового знищення» [4, 58]. Соціальні медіа перетворили інформаційну війну з такої, що обслуговує фізичну війну, на щонайменше рівну ій.

Основний вектор в інформаційній війні спрямований на психіку військовослужбовців [5]. Фейкові повідомлення покликані видозмінити реальність військовослужбовця. При цьому кількість військовослужбовців, які можуть підпадати під вплив фейкових повідомлень слід вираховувати не зі списочної чисельності ЗС України та інших військових формувань, а 3 чисельності військовозобов'язаних та молоді призовного віку, які згідно чинного законодавства в разі повномасштабного вторгнення будуть призвані по мобілізації. А це вагома частина населення. При цьому фейки спрямовуватимуться i на членів сімей та родичів військовослужбовців, які в тій чи іншій мірі мають на них вплив.

Виходячи із статистики озвученою ексміністром оборони України Михайлом Ковалем, - зрадили Батьківщині та перейшли на бік Російської Федерації під час анексії Криму в 2014 році 70,4\% військовослужбовців ЗС України, які проходили службу в Криму, 70,3\% військовослужбовців

Держприкордонслужби, 90,2 \% працівників MBC, 80,2\% працівників СБУ. Тобто, майже всі ті, хто повинен був захищати Крим, виявилися зрадниками [6]. Вражаюча для нас статистика підтверджує, що фізичне поле бою вже не є найважливішою ареною збройного конфлікту. Комплексний погляд на початок російської агресії в Криму, за даними Д. Кулеби дає змогу аналітикам дійти висновку, що розпалювання ненависті до українців із залученням державних ресурсів $є$ одним 3 інструментів ведення війни $[7,55]$.

Стверджуємо, що більшість фейкових повідомлень, що спрямовані на військовослужбовців стосуються війни та політики й грунтуються на прокачуванні «зрад» i «перемог». Війна та політика нерозривні, а проблема, 3 якою ми зараз стикаємося, амбівалентна: кордони між політикою та війною ніколи не були такими розмитими, а політика - такою нестабільною. Все це стало можливим завдяки соціальним медіа.

Д. Патрикаракос зазначає, що соціальні медіа руйнують старий порядок трьома способами: часом, простором i методом. Розмивається початок і кінець війни, позаяк інформаційний вимір збройного конфлікту може розгорнутися задовго до активних бойових дій і триватиме після завершення бойових операцій $[2,339]$.

Аналіз останніх досліджень і публікацій дає підстави стверджувати, що сьогодні приватна практика психологів наповнюється випадками інтернет-адиктивного розладу (InternetAddictionDisorder). Психологи, залежність від віртуальної мережі ставлять на один щабель 3 алкогольною та наркотичною залежністю, вважаючи, що такий вид деструктивної поведінки порушує нормальне функціонування особистості в соціумі, дезорганізовує іiі та посилює фрустрацію від нереалізованих потреб реального життя.

Методи дослідження. Реалізуючи мету статті ми виходимо з того, що теоретичне дослідження фейку, з методологічної точки зору, належить до вищого рівня наукового знання, оскільки розкриває і обгрунтовує 


\section{Питання психології}

більш глибинні та суттєві сторони цього феномену. Нами задіяно наступні загальнонаукові методи: аналіз, синтез, індукція, дедукція, порівняння, формалізація, абстрагування, моделювання. Використання історичного методу дало змогу всебічно розкрити дослідження фейку в хронологічній послідовності, встановивши його внутрішню сутність, закономірності впливу на цільову аудиторію та протиріччя в декодуванні повідомлень.

\section{Результати і обговорення.}

Фейк в інформаційній

Література воєнно-історичного змісту переповнена прикладами щодо дезінформації у воєнний час. Вже у 1312 році до н.е. хетам вдалося за допомогою неправдивої інформації ввести в оману військо єгиптян на чолі 3 фараоном Рамсесом II і в бою під фортецею Кадеш завдати йому несподіваного удару. Це змусило Рамсеса II відмовитись від подальшого штурму Кадеша й повернутись в Єгипет.

Незважаючи на щільне місце фейку в історії війн та політиці впродовж багатьох століть, вивчення його особливостей розпочалось відносно недавно й пов'язано із швидким розвитком одного із його основних джерел існування - соціальних мереж. Наразі не існує єдиного наукового підходу, щодо визначення поняття фейк. I. Мудра під фейком розуміє спеціально створене повідомлення, подію (журналістський матеріал), що містить неправдиву (перекручену) інформацію, й покликане дискредитувати певну особу чи групу осіб в очах аудиторії [8].

Фахівці Національного інституту стратегічних досліджень у своїй аналітичній доповіді «Фейки, пропаганда, дезінформація та виборчий процес: як нам захистити демократичні практики?» пропонують відокремлювати два основні підходи щодо розуміння та визначення фейків: «широкий» та «вузький». Згідно 3 «широким» підходом fake ототожнює в собі все, що є несправжнім та/або породжує несправжнє. Це, як правило, несправжні сайти, несправжні сторінки від імені відомих осіб, сторінки людей, які видають себе в мережі Інтернет за інших, фотографії редаговані у фоторедакторах, аудіо переговори відомих політиків, підроблені ліки. Відповідно до «вузького» підходу, поняття «фейк» розглядається коли йдеться виключно про новини (fake news) [9, 18].

Б. Козловський у праці «Максимальный репост. Як соціальні мережі заставляють нас вірити фейковим новинам» зауважує: «Фейкові новини - груба підробка під новини, що будучи не здатними пройти базову перевірку на достовірність, впливають на психіку мільйонів людей» [10]. За допомогою фейкових повідомлень суспільство здатне змінювати й насаджувати людині інші норми, цінності, установки та стереотипи поведінки [11].

Оскільки єдиного загальноприйнятого поняття фейку немає, відсутній і його чіткий поділ. Умовно їх слід класифікувати за такими критеріями: джерелом поширення (фейки по телебаченню, радіо, фейки друкованих видань (газети, журнали, брошури), фейки інтернету (сайти, соціальні мережі, месенджери); характером сприйняття (аудіофейки, відеофейки, фейки-зображення (меми, фотожаби, карикатури), текстові повідомлення (статті), змішані (об'єднують відео, зображення та текст); характером створення (непрофесійні (створюються ботами, тролями, громадянами), професійні (створюються журналістами, спецслужбами); метою створення (фейки, що рекламують когось/щось (застосовуються в маркетингу), фейки, що приносять прибуток (застосовуються на сайтах для збільшення кількості відвідувачів), фейки, для досягнення політичних амбіцій (плямують репутацію, обіцяють нечувані привілеї виборцям), фейки для досягнення цілей інформаційної війни (сіють паніку серед людей, розпалюють міжнаціональну (расову, релігійну) ворожнечу, поширюють хибні думки щоб заплутати, відволікти від правди, підірвати довіру до державних інститутів). Виходячи $з$ останнього, фейки - особливий інструмент пропаганди та дезінформації в інформаційній війні. Загальна особливість усіх фейків - обманути, посіяти сумніви й переконати аудиторію у правдивості поданого повідомлення.

Д. Патрікаракос зазначає, - «Чим більше сумнівів ви можете посіяти у свідомості людей 3 певного питання, тим дужче послабите їхню схильність розпізнавати істину, коли вони іï бачать чи чують. Це головне підгрунтя російської 


\section{Питання психології}

пропаганди $[2,202]$. Фейки осмислені в дії та спрямовані на оману цільової групи, підрив репутації інституту чи певної особи [11].

За даними дослідження журналу Science (березень 2018 р.,) в якому за основу взято $100 \quad 000$ історій (правдивих і фейкових), що поширювалися 4,5 млн. разів у період з 2006 по 2017 роки виявлено, що фейкові повідомлення поширюються $\mathrm{y}$ шість разів швидше за правду [12]. Виникає запитання: чому люди довіряють фейковій інформації значно більше, аніж правдивій інформації? Систематизуючи шлях, який проходить фейкова інформації задля досягнення кінцевого результату (щоб у неї повірили) його можна розділити на три етапи: 1) привернення уваги; 2) переконання; 3) прийняття рішення. Причому всі три етапи мають спрацювати. Виключення будь якого етапу із цього списку унеможливлює досягнення фейком кінцевої мети. Розглянемо, якими основними методами досягаються ці процеси.

\section{Властивості фейку, щиодо}

привернення уваги. Згідно із статистикою Internet live status користувачі впродовж дня здійснюють біля 600 млн. запитів в програмі Google, переглядають біля 580 млн. відео на YouTube, а кількість активних користувачів на Facebook досягає більше 200 млн. одночасно i ці дані продовжують збільшуватись [13]. Таким чином, ми постійно стикаємось 3 проблемою вибору. Задамося запитанням: яким чином особа відсіює непотрібну інформацію, не потонувши в океані альтернатив? Спершу процес привернення уваги досягається за рахунок іiі зовнішніх факторів. Фізичні характеристики сигналів (гра світла і тіні, підбір відповідної гамми кольорів, правильне розташування тексту, влучно підібрана музика відео сюжету) відіграють не аби яку роль. Найбільш грунтовні та системні дослідженнями в розрізі привернення уваги проведено в сфері нейромаркетингу. За даними В. Вудвуд, нейромаркетинг - новітній комплекс нейроприйомів, нейрометодів та нейротехнологій, який допомагає встановлювати комунікаційний зв'язок між підприємством та споживчою аудиторією [14]. На сьогодні він широко застосовується для створення ефективної реклами, адже першочергове завдання реклами як і фейкупривернути уваги, створити вау-ефект.

В праці «Нейромаркетинг - новітній інструмент впливу на поведінку споживачів у недосконалих умовах ринкової економіки України» В. Вудвуд виділяе три основні підходи впливу нейромаркетингу на підсвідомість людини: аромамаркетинг вплив за допомогою аромату; мерчандайзинг - вплив за допомогою кольору, зображень, розміщення; аудіомаркетинг - вплив за допомогою звуку [14]. Слідуючи за Максом Люшером, вважаємо, що колір не лише викликає відповідну реакцію людини залежно від іiі емоційного стану, а й певним чином впливає на емоції. Якщо червоний - налаштовує на рішучість, спонукає людину до вчинку, помаранчевий - активізує енергопотенціал, породжує оптимізм; то жовтий - сприяє комунікабельності, а зелений - пом'якшує, знімає гостроту переживань [15].

Правильно підібраний шрифт впливає на увагу. Одне і те ж слово, набране різними шрифтами, по-різному сприйматиметься. На сьогодні серед значного розмаїття шрифтів у медіа здебільшого використовують два основних: 3 зарубками (типу Time New Romans), без зарубок (типу Arial). Шрифти iз зарубками легше читаються у друкованих працях. Зарубки збільшують контраст між буквами роблячи їх відмінними, що сприяе кращому декодуванню мозком букв. Читаючи шрифт без зарубок, мозок витрачає більше часу на те, щоб декодувати букву, тому що іiі форма не настільки відмінна. Шрифти без зарубок використовують в Інтернеті оскільки вони не втрачають своїх властивостей при збільшені чи зменшенні. Як справедливо наголошує О. Красницька, в інформаційному соціумі переповненому інформацією довгі роз'яснення та тексти не користуються популярністю. Люди просто не хочуть витрачати на це час, вважаючи, що ту ж саму новину можна дізнатись із значно коротшого повідомлення. Тому фейки для виграшу конкуренції за увагу, як правило короткі за своїм змістом [16].

За даними В. Кириченко для сформування певного ставлення про об’єкт на основі інформаційного опису, достатньо короткого тексту та візуального підкріплення у вигляді фото чи іншого зображення. Обробляючи 25-60 інформаційних блоків за один сеанс 


\section{Питання психології}

користування соціальною мережею досліджувані, 3 метою економії часу та ресурсів, вдаються до спрощеного методу обробки інформації. Після аналізу заголовку та супроводжуючого графічного зображення, досліджувані формують певне уявлення про те, що має бути у змісті основного текстового блоку, на основі загальноприйнятого ставлення до об'єкту опису в інформаційному середовищі «МИ» [3, 198]. Найбільше шансів захопити увагу аудиторії має короткий текст i якомога коротше відео [7, 53; 16].

Не схвалення особою довгих дописів у фейсбуці пояснюється тим, що несвідомо вона побоюється пропустити якийсь важливий допис [7, 136]. Д. Патрикаракос описує інтерв'ю 3 Даніелем Рубінштейном відповідальним за контент усіх англомовних соціальних медіа, який створював підрозділ прес-служби Армії оборони Ізраїлю. Останнім запроваджено практику викладання інформації у 140 символах твіту або в коротких фейсбучних постах. Це дало чудовий результат поширювати наративи у міжнародну спільноту потрібного Ізраїлю бачення, щодо військового конфлікту в Секторі Газа.

Значну кількість досліджень присвячено впливу музики на психічний стан особистості. О. Шевяков доводить, що прослуховування одних музичних композицій вводить слухача у врівноважений, гармонійний, здоровий стан, покращує настрій, знижує відчуття тривожності. Інші ж композиції навпаки викликають у слухача негативні емоції (навіть на підсвідомому рівні), відчуття тривоги, пригніченості, страху, агресії [17]. B YouTube надзвичайно велику кількість переглядів зібрав контент, в якому представники Аль-Каїди записували короткі відео про успіх ІДІЛУ, що супроводжувались саундтреками 3 доволі красивих, хвилюючих нашидів (ісламських гімнів спеціально укладених 3 метою похвали, поклоніння або молитви, що зазвичай звертаються до божества чи видатного діяча).

В процесі кодування фейкового повідомлення надзвичайно велика роль відводиться символам - особливій, опосередкованій формі відображення. У символі ніколи предмети не названі своїми іменами, швидше навпаки, символ подає нашим почуттям відображення предметів у завуальованій формі (їх першими захоплює енергія символу): одні сторони докладно розкриває, інші (теж невідомі) - покриває завісою, яка знижує контрастність зображеного i робить його таємницею. Символ дає людині завдання: в його будові треба знайти передусім задачу дії. У той же час символ - маяк, що освітлює людині шлях до майбутнього, адже задає спосіб розв'язання закодованої в собі задачі. Символ - принцип побудови діяльності [18]. Деяка бронетехніка представників НЗФ у 2014 році на території Донецької та Луганської областей переміщувалась 3 прапорами на яких були зображені святі (Ісус Христос). Такі дії мали за мету викликати у військовослужбовців 3С України враження, що діяльність непризнаних ЛДНР виправдана та відповідає християнським нормам.

Ведучи мову про привернення уваги певним повідомленням доцільно згадати його внутрішні фактори - актуальність цього повідомлення для даної людини, ступінь його новизни, відповідність потребам і емоційному настрою. Навряд чи військовослужбовці звернуть увагу на повідомлення про існування НЛО, існування містичних тварин у Чорнобильській зоні, чи масові теорії змов світових масонів, оскільки це в меншій мірі стосується їхньої діяльності, хоча такі фейки також мають свою аудиторію. Військовослужбовців здебільшого цікавитимуть новини про хід бойових дій в зоні проведення ООС, про відношення суспільства та уряду до військових, про керівництво силових структур, а також політичні процеси пов'язані насамперед із війною. Саме в такій категорії новин військові мають бути особливо обачними, щоб не піддатись маніпулятивному впливу.

Когнітивні упередження, як інструмент переконання в прийнятті хибних рішень. Проте лише одного привернення уваги до фейку замало, потрібно щоб у нього повірили. Саме тому наступним його завданням $є$ переконання. Для цього фейк слід наділити різними когнітивними упередженнями, ілюзіями та ефектами.

С. Паулус розкриваючи когнітивні упередження у праці «Психологія оцінки та прийняття рішень» зауважує, що сприйняття 


\section{Питання психології}

знаходиться під сильним впливом упереджень, створених колишніми взаємодіями 3 навколишнім середовищем. Коли у людей досить практичного досвіду в певній ситуації, вони часто бачать те, що очікують $[19,19]$.

Значний пласт наукових досліджень присвячений когнітивним упередженням напрацьований психологами Еймосом Тверські та Деніелом Канеманом. На їх думку когнітивні упередження в вузькому розумінні $\epsilon$ помилками мислення, яких припускає особа, спираючись на хибні переконання та стереотипи. Іншими словами, це помилкові рішення, які ми приймаємо через надмірну впевненість.

Р. Барон, виокремлює наступні умови, що максимізують вплив когнітивних упереджень: високий рівень невизначеності, новизни, дефіциту часу, інформаційного перевантаження та емоційного напруження [20]. Як бачимо, це ідеальні умови в яких існують фейки. Розглянемо найпоширеніші когнітивні упередження, які стимулюють особу повірити фейковому повідомленню.

Ефект повторення, або ефект ілюзї правди грунтується на тому, що особи ідентифікують інформацію як правдиву лише тому, що чули іï декілька разів. Такий ефект дуже влучно використовує для своєї пропаганди Російська Федерація. Інформацію, що має скласти певне, в більшості випадків хибне враження транслюють по багатьох телеканалах та поширюють у багатьох інтернет джерелах. Дослідники американської корпорації RAND влучно визначили чотири ключові ознаки російської пропаганди: великий обсяг i багатоканальність; швидкість, безперервність і повторення [7, 111]. Варто підкреслити, що саме масштабність поширення фейків спричиняє найбільший психологічний вплив на особистість. Сучасна людина під впливом медіа, що нав'язують йй свою думку, може втрачати власну автентичність, здатність самостійно робити вибір та критично мислити $[5 ; 11]$.

Ефект первинності (в ряді джерел якірний ефект) полягає в тому, що людина більше здатна довіряти першому джерелу інформації, аніж усім наступним, навіть якщо ця інформація із сумнівного джерела. Інформації про певну подію яка перша попала на стрічку соціальної мережі чи на екрани телебачення довірять більше, аніж інформації про ту ж саму подію яка з'явилась пізніше. Так, за лічені хвилини після збиття МН-17, в мережі появилась інформація про причетність до цієї події українських військових, саме цей ефект, за даними російських пропагандистів i мав зіграти вирішальну роль, щоб у цей фейк повірили.

Ефект недавності. Встановлено, що в певних випадках повідомлення озвучене останнім може викликати більше враження, аніж назване першим. Питання полягає в тому в яких випадках сильнішим $\epsilon$ ефект первинності, а в яких ефект недавності. Фахівці в області поведінкової i експериментальної психології $€$. Кемпбелл і У. Міллер в спеціально проведеному експерименті встановили, що якщо висвітлюється інформація, рішення по якій має бути винесено протягом тижня, подавати іï слід першою. 3 іншого боку, якщо між висвітленням двох повідомлень буде перерва, а рішення буде виноситися після другого повідомлення - поширювати його слід другим.

Ефект обрамлення. В залежності від подачі повідомлення (в позитивному чи негативному ракурсі) воно буде впливати на вибір людини. Так, якщо до військовослужбовців довести інформацію, що в зоні виконання бойових завдань дії наших військ не підтримує $26 \%$ місцевого населення - це може викликати в них певну тривожність, а якщо навпаки переформулювати даний факт і повідомити, що $74 \%$ мешканців лояльно ставляться до дій наших військ це придасть впевненості. Одна і таж інформація доведена у різних формах матиме різний вплив на поведінкову активність військовослужбовця.

Ефект хибної пам'яті. С. Паулус доводить, що спогади не $\epsilon$ копіями наших минулих вражень, що зберігаються в пам'яті. Скоріш навпаки: вони створюються в той час, коли ми їх відтворюємо [19]. Цікавим видається дослідження Е. Лофтус і Дж. Палмера, в якому 50 студентам демонструвався однохвилинний сюжет, що містив чотирьох секундний епізод зіткнення кількох машин. Ключовим було запитання: «Чи пам'ятають студенти, що бачили розбите скло в епізоді автокатастрофи?» $35 \%$ досліджуваних відповіли «Так», хоча сюжет такого не містив. Це свідчення того, що відтворюючи особи часто користуються 


\section{Питання психології}

логічними висновками, що доповнюють загублені деталі; асоціативні спогади змішуються 3 спогадами справжніми й іншою супутньою, навіть побічно пов'язаною 3 «матеріалом» інформацією. Акцентуючи людину на пригадуванні й концентруючи при цьому увагу на вигідних для нас подіях, ми можемо маніпулювати ними.

Навіть найбільш досвідчена у прийнятті рішень людина піддається упередженням, пов'язаним 3 роботою пам'яті, i немає кращого способу уникнути їх, аніж ретельне ведення записів минулих подій (наприклад, зустрічей, важливих діалогів і угод) [19, 33].

Eфект ореола полягає в тому, що коли особі властиві певні досягнення чи заслуги в одній галузі - ій автоматично приписують $\mathrm{i}$ інші бажані якості, яких ця людина швидше за все не має. Таким ефектом наділяє російська пропаганда президента своєї держави В. Путіна. Його висвітлюють блискучим політиком, військовим, економістом, спортсменом, а деякі навіть ототожнюють із святим, який може спасти весь світ. Цей ефект застосовується для створення великої аудиторії, яка в особі президента РФ має побачити лідера не лише Росії але всього «руського миру» та не сумніватись, щодо ведення ним внутрішньої та зовнішньої політики.

В. Кириченко зауважує, що в інформаційному суспільстві референти думки, або персони, які займають рольові позиції, що дають змогу поширювати певну інформацію, займають статусно вищу позицію аніж пересічні громадяни. До інформації, яка передається у межах позиції, умовно назвемо іiі «рівний-рівному», існує певний рівень недовіри, що породжується природним бажанням людини перевірити істинність знань, встановити можливість існування тих чи інших фактів, визначити ступінь особистісної причетності до подій та явищ описаних в інформаційному повідомленні [3, 167].

Відповідно до ефекту напівправди негативні сторони явища ототожнюються 3 самим явищем. Характерним для «вдалого» фейку $є$ те що він має містити хоча б долю правдивої інформації. Підгрунтям виникнення наративу про процвітання тотального фашизму в Україні став факт неоднозначної діяльності ОУН в період Другої Світової війни, коли ОУН була розділена на дві фракції: ОУН(б), яка боролась за незалежність України як 3 фашистами так із червоною армією та ОУН(м), які були колаборантами проте жорстко засуджуються як українськими істориками так і українським суспільством в цілому.

Основу ефекту інформаційної бульбашки складає алгоритм соціальних мереж. Наші цифрові сліди стали чи не найціннішим активом сучасного світу. Вони повідомляють, у що ми віримо, що любимо, що ненавидимо, до чого схильні, де й що купуємо, з ким спілкуємося. Вони покликані робити наше життя зручнішим i щоб ефективніше продавати нам товари, послуги, переконання та емоції $[10,40] .3$ погляду комунікативного світу ми - це наші персональні дані. Володіння ними дає змогу будувати для нас будь-яку реальність [7, 41].

Алгоритм сучасних соціальних мереж налаштовано так, що людина бачитиме лише ту інформацію, яку схвалювала на сторінках раніше й залишатиметься осторонь від тих тверджень яких не підтримує. Система просто не буде iii показувати, що додасть вам впевненості у своїх поглядах. Ефект інформаційної бульбашки - $\epsilon$ станом інтелектуальної ізоляції, явищем, спричиненим результатами персоналізованого пошуку, в якому алгоритм вебсайту вибірково припускає, яку інформацію користувач хотів би бачити, базуючись на інформації про користувача (як-от розташування, поведінка «після кліка» та історія пошуку). Як наслідок, користувачі відділяються від інформації, яка не відповідає їх точкам зору, фактично ізолюючись у власних культурних або ідеологічних бульбашках. Якщо в інформаційну бульбашку людини потрапить фейкове повідомлення, інформаційний простір розриватиме від неправдивої інформації i найймовірніше вона в неї повірить.

Дія фейку на психічне здоров'я військовослужбовців та їх поведінкову aкmивність. Небезпечна дія фейку криється в тому, що він викликає певні емоційні переживання, що накладають негативний відбиток на психічне здоров'я військовослужбовця. Сьогодні фейк слід розглядати значно ширше, аніж просто неправдиву інформацію. В. Кириченко стверджує, що шкідливою $є$ не сама 


\section{Питання психології}

інформація, а реакція на неї, яка є настільки передбачуваною - наскільки адекватно та повно зрозуміє повідомлення кінцевий адресат. У своїй більшості інформація має раціональну основу, але іiі дієвість на $100 \%$ залежить від емоційного стану, який викличе вона у цільової аудиторії [3].

Більшість дослідників поділяють інформаційний вплив на раціональний, що базується на логіці та мисленнєвій діяльності людини (констатація фактів, статистичні узагальнення) та нераціональний, що у своїй основі містить емоційні переживання та афективний вплив на споживача.

За Г. Мюнстбергером, найбільш природній шлях задля формування певної реакції на інформацію у населення $\epsilon$ формування сильних емоційних переживань: страху, надії, любові, співпереживання. Інформація, побудована на нераціональному впливі зустрічається набагато частіше. Такий вид інформаційної продукції спрямований на некритичне сприйняття інформації, сприйняття емоційного фону, утворення певного емоційного ставлення до явища [21]. Фейкові повідомлення, що спрямовані на військовослужбовців здебільшого покликані викликати негативні емоції: хвилювання, тривогу, розпач, образу, розчарування, гнів, страх $[3 ; 22 ; 23]$.

Негативно забарвлена емоція, виражає відчуття невизначеності, очікування негативних подій, важковизначені передчуття [24]. В. Кириченко вважає, що у стані загальної невизначеності більшість 3 того, що відбувається навколо, а особливо те, що не входило в усталену картину світу особистості, сприймається радше негативно, 3 певною осторогою, що додає до загального психічного виснаження ще й емоційне вигоряння. У такому стані пересічні особи здатні повірити у будь-що, аби хоча б на рівні примарних ідей зберегти цілісність своє психіки та певним чином впорядкувати внутрішній життєвий простір.

Серед фейків здатних викликати тривогу чимало таких, що вимальовують невтішне майбутнє. Неодноразово російські 3MI поширювали інформацію, що українські військові нестимуть відповідальність за здійснення так званих, на їх думку «злочинів», що у разі будь-яких загострень бойових дій вище військове та політичне командування їх залишить на призволяще, що через війну економіка держави не витримає i розпадеться на декілька окремих частин та інші. Найбільш травмуючими є стресори майбутнього, які змушують особистість постійно готуватися до подій, що можуть трапитися у ії житті. Тривоги та невдачі майбутнього, які можуть бути як реальними так і надуманими, здатні створювати більший стрес, аніж реальна фізична небезпека [3].

Загроза майбутнього - сильний психотравмуючий фактор, що призводить до появи цілої системи маніпулятивних технологій. Маніпуляції 3 майбутнім у вигляді публічних пророцтв, аналізу прикмет, ворожіння, змінюють громадське ставлення швидше, аніж факти та логічні доводи, що спокушає використовувати їх у процесі управління геополітичними процесами, суспільними настроями та світоглядними уявленнями цілих народів.

Велике значення, особливо для військовослужбовців відіграє взаємозв'язок емоцій з фізіологічними змінами в організмі. Фізіологічні зрушення відбуваються при багатьох емоціях як вторинне пристосувальне явище. Схема етапів виникнення емоцій i супутніх їм фізіологічних зрушень може мати такий вигляд: подразник - збудження таламуса емоція - фізіологічні зміни.

В нашому випадку саме фейкова інформація $\epsilon$ подразником, що викликає емоції, а в подальшому і фізіологічні зміни в організмі військовослужбовця. Негативні емоції (розчарування, образа, гнів) можуть призводити до дезорганізації поведінки й діяльності, порушувати цілеспрямовану дію, спричиняти порушення пам'яті, навичок, призводити до заміни складних дій простішими. Військовослужбовець при гніві почуває себе роздратовано, при сумі гальмується моторика, що сповільнює не лише фізичну, але й розумову активність.

\section{Висновки.}

За своєю сутністю, фейк - різновид інформаційної зброї спрямованої дії, що застосовується для здійснення прихованої трансляції певних ідей або меседжів. Останні, в свою чергу, використовуються для зміни емоційних та психологічних установок певної цільової аудиторії. В ідеалі, наслідком поширення фейкового повідомлення має стати досягнення стану 


\section{Питання психології}

масового когнітивного дисонансу у представників цільової групи проти яких застосовано цей вид інформаційної зброї. Людині, що знаходиться в такому стані, дуже легко нав'язувати певні рішення або моделі поведінки, які працюють на користь атакуючої сторони. Негативна дія фейків перш за все покликана вражати емоційну, мотиваційну, соціальну, екзистенційну та інтелектуальну сторони психіки військовослужбовця.

\section{Список використаних джерел}

1. Дослідження АрміяInform: Безпека військових у соціальних мережах. АрміяInform: офіц. вебсайт. URL: https://armyinform.com.ua/2020/02/ doslidzhennya-armiyainform-bezpeka- jskovyh-u-soczialnyhmerezhah/

2. Патрикаракос Д. Війна у 140 знаках. Як соціальні медіа змінюють конфлікти у XXI столітті. Київ : Yakaboo Publishing, 2019. 352 c.

3. Кириченко В. В. Формування картини світу особистості в сучасному інформаційному суспільстві. Житомир : Вид-во ЖДУ ім. І. Франка, 2020. 504 с.

4. Інформаційна війна і національна безпека: монографія / Ткачук П. П., Гула Р. В., Сивак О. І., Щурко О. М., Шемчук В. В. Львів : АСВ, 2015. 256 с.

5. Хміляр О.Ф., Олійник Т. Р. Диструктивна дія фейкових повідомлень на психічне здоров'я військовослужбовців /The process and dynamics of the scientific path: collection of scientific papers «SCIENTIA» with Proceedings of the I International Scientific and Theoretical Conference (Vol. 2), February 26, 2021. Athens, Hellenic Republic: European Scientific Platform, 2021. P. 84 - 88.

6. Статистика зради: скільки військових у Криму зрадили Батьківщину у 2014. ZN.ua: офіц. вебсайт. URL: https://zn.ua/ukr/UKRAINE/statistika-zradi-skilki-viyskovih-u-krimu-zradili-batkivschinu-u-2014303448 .html (Дата звернення 02.10.2020).

7. Кулеба Д. Війна за реальність: як перемагати у світі фейків, правд і спільнот. Київ : Книголав, 2019. $384 \mathrm{c}$.

8. Мудра I. М. Поняття «фейк» та його види у ЗМІ. Теле- та радіожурналістика. 2016. Вип. 15. С. $184-188$.

9. Дубова Д. В. Фейки, пропаганда, дезінформація та виборчий процес: як нам захистити демократичні практики? Київ : ТОВ «Видавництво Сталь», 2019. 254 с.

10. Козловський Б. Максимальный репост. Как соцсети заставляют нас верить фейковым новостям. Альпіна Паблішер, 2018. 193 с.

11. Khmiliar, O., Piankivska, L., Krasnytska, O., \& Cherevychnyi, S. (2021). Transformational Influence of Fake Messages on the Behavioral Activity of an Individual: Psycholinguistic Aspect. Postmodern Openings, Vol.

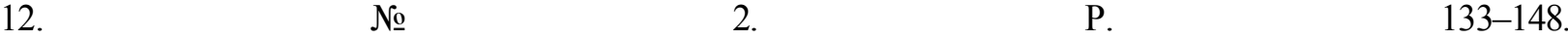
https://doi.org/10.18662/po/12.2/300.Web of Science.https:/lumenpublishing.com/iournals/index.php/po/article/ view/3600.https://lumenpublishing.com/journals/index.php/po/article/view/3600/2931

12. The spread of true and false news online. Science: офіц. веб-сайт. URL:https://science.sciencemag.org/content/359/6380/1146/tab-pdf. (Дата звернення 28.09.2020).

13. Internet live stats. URL:https://www.internetlivestats.com (Дата звернення 02.10.2020).

14. Вудвуд В. В. Нейромаркетинг - новітній інструмент впливу на поведінку споживачів у недосконалих умовах ринкової економіки України. Інноващійна економіка. 2013. № 7. С. 210 - 212.

15. Макс Люшер. Цветовой тест Люшера. Эксмопресс, 2002. 103 с.

16. Красницька Ольга. Педагогічна майстерність викладача вищої військової школи : підручник. Київ : Кондор, 2020. 528 с.

17. Шевяков О. В., Славська Я. А. Вплив музики на психологічний стан учнів. Актуальні проблеми педагогіки, психології та професійної освіти. 2016. № 1. С. 22 - 27.

18. Хміляр О. Ф. Психологія символічної регуляції дій і вчинків особистості [монографія]. К. : ПП «Золоті ворота», 2016. 379 с.

19. Паулус С. Психологія оцінки і прийняття рішення. Інформаційно-видавничий дім «Філінь», 1998. $368 \mathrm{c}$.

20. Baron R. A. Cognitive Mechanisms in Entrepreneurship: Why and When Entrepreneurs Think Differently than Other People. Journal of Business Venturing. 1998. 13(4). P. 275 - 294.

21. Хміляр О. Ф. Критичне та позитивне мислення офіцера. Наукові записки Національного університету «Острозька академія». Серія «Психологія». 2018. № 7. С. $72-76$.

22. Курбан О. В. Фейки у сучасних медіа: ідентифікація та нейтралізація. Бібліотекознавство. Документознавство. Інформологія. 2018. № 3. С. $96-103$.

23. Почепцов Г. «Сайти по боротьбі з фейками читають фахівці, а населення споживає самі фейки». Mind: веб-сайт. URL: https://mind.ua/publications/20223410-georgij-pochepcov-sajti-po-borotbi-z-fejkamichitayut-fahivci-a-naselennya-spozhivae-sami-fejki (Дата звернення 16.02.2021). 


\section{Питання психології}

24. Красницька Ольга. Лідерство та риторика у професійній діяльності офіцера. Актуальні питання гуманітарних наук : міжвузівський зб. наук. пр. молодих вчених Дрогобицького державного педагогічного університету імені Івана Франка. Дрогобич : вид. дім «Гельветика», 2020. Вип. 28. Т. 2. С. 181-187. URL: http://journals.uran.ua/index.php/2308-4855/article/view/208672 (дата звернення 02.08.2020). DOI: https://doi.org/10.24919/2308-4863.2/28.208672

\section{References}

1. Doslidzhennia ArmiiaInform: Bezpeka viiskovykh u sotsialnykh merezhakh. ArmiiaInform: ofits. vebsait. URL: https://armyinform.com.ua/2020/02/ doslidzhennya-armiyainform-bezpeka- jskovyh-u-soczialnyhmerezhah/

2. Patrykarakos D. Viina u 140 znakakh. Yak sotsialni media zminiuiut konflikty u XXI stolitti. Kyiv : Yakaboo Publishing, 2019. $352 \mathrm{~s}$.

3. Kyrychenko V. V. Formuvannia kartyny svitu osobystosti v suchasnomu informatsiinomu suspilstvi. Zhytomyr : Vyd-vo ZhDU im. I. Franka, 2020. 504 s.

4. Informatsiina viina i natsionalna bezpeka: monohrafiia / Tkachuk P. P., Hula R. V., Syvak O. I., Shchurko O. M., Shemchuk V. V. Lviv: ASV, 2015.256 s.

5. Khmiliar O. F., Oliinyk T.R. Dystruktyvna diia feikovykh povidomlen na psykhichne zdorovia viiskovosluzhbovtsiv /The process and dynamics of the scientific path: collection of scientific papers «SCIENTIA» with Proceedings of the I International Scientific and Theoretical Conference (Vol. 2), February 26, 2021. Athens, Hellenic Republic: European Scientific Platform, 2021. P. 84 - 88.

6. Statystyka zrady: skilky viiskovykh u Krymu zradyly Batkivshchynu u 2014. ZN.ua: ofits. veb-sait. URL: $\quad$ https://zn.ua/ukr/UKRAINE/statistika-zradi-skilki-viyskovih-u-krimu-zradili-batkivschinu-u-2014303448_html (Data zvernennia 02.10.2020).

7. Kuleba D. Viina za realnist: yak peremahaty u sviti feikiv, pravd i spilnot. Kyiv: Knyholav, 2019. $384 \mathrm{~s}$. 188.

8. Mudra I. M. Poniattia «feik» ta yoho vydy u ZMI. Tele- ta radiozhurnalistyka. 2016. Vyp. 15. S. $184-$

9. Dubova D. V. Feiky, propahanda, dezinformatsiia ta vyborchyi protses: yak nam zakhystyty demokratychni praktyky? Kyiv : TOV «Vydavnytstvo Stal», 2019. $254 \mathrm{~s}$.

10. Kozlovskyi B. Maksymalnыi repost. Kak sotssety zastavliaiut nas veryt feikovыm novostiam. Alpina Pablisher, 2018. 193 s.

11. Khmiliar, O., Piankivska, L., Krasnytska, O., \& Cherevychnyi, S. (2021). Transformational Influence of Fake Messages on the Behavioral Activity of an Individual: Psycholinguistic Aspect. Postmodern Openings, Vol.

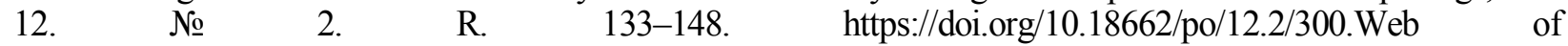
Science.https://lumenpublishing.com/journals/index.php/po/article/view/3600.https://lumenpublishing.com/journ als/index.php/po/article/view/3600/2931

12. The spread of true and false news online. Science: ofits. veb-sait. URL:https://science.sciencemag.org/content/359/6380/1146/tab-pdf. (Data zvernennia 28.09.2020).

13. Intrrnet live stats. URL:https://www.internetlivestats.com (Data zvernennia 02.10.2020).

14. Vudvud V. V. Neiromarketynh - novitnii instrument vplyvu na povedinku spozhyvachiv u nedoskonalykh umovakh rynkovoi ekonomiky Ukrainy. Innovatsiina ekonomika. 2013. № 7. S. 210-212.

15. Maks Liusher. Tsvetovoi test Liushera. Эksmopress, 2002. $103 \mathrm{s.}$

16. Krasnytska Olha. Pedahohichna maisternist vykladacha vyshchoi viiskovoi shkoly : pidruchnyk. Kyiv : Kondor, 2020. $528 \mathrm{~s}$.

17. Sheviakov O. V., Slavska Ya. A. Vplyv muzyky na psykholohichnyi stan uchniv. Aktualni problemy pedahohiky, psykholohii ta profesiinoi osvity. 2016. № 1. S. $22-27$.

18. Khmiliar O. F. Psykholohiia symvolichnoi rehuliatsii dii i vchynkiv osobystosti [monohrafiia]. K. : PP «Zoloti vorota», 2016. $379 \mathrm{~s}$. $368 \mathrm{~s}$.

19. Paulus S. Psykholohiia otsinky i pryiniattia rishennia. Informatsiino-vydavnychyi dim «Filin», 1998.

20. Baron R. A. Cognitive Mechanisms in Entrepreneurship: Why and When Entrepreneurs Think Differently than Other People. Journal of Business Venturing. 1998. 13(4). p. 275 - 294.

21. Khmiliar O.F. Krytychne ta pozytyvne myslennia ofitsera. Naukovi zapysky Natsionalnoho universytetu «Ostrozka akademiia». Seriia «Psykholohiia». 2018. № 7. S. $72-76$.

22. Kurban O. V. Feiky u suchasnykh media: identyfikatsiia ta neitralizatsiia. Bibliotekoznavstvo. Dokumentoznavstvo. Informolohiia. 2018. № 3. S. 96 - 103.

23. Pocheptsov H. «Saity po borotbi z feikamy chytaiut fakhivtsi, a naselennia spozhyvaie sami feiky». Mind: veb-sait. URL: https://mind.ua/publications/20223410-georgij-pochepcov-sajti-po-borotbi-z-fejkamichitayut-fahivci-a-naselennya-spozhivae-sami-fejki (Data zvernennia 16.02.2021).

24. Krasnytska Olha. Liderstvo ta rytoryka u profesiinii diialnosti ofitsera. Aktualni pytannia humanitarnykh nauk : mizhvuzivskyi zb. nauk. pr. molodykh vchenykh Drohobytskoho derzhavnoho pedahohichnoho universytetu imeni Ivana Franka. Drohobych : vyd. dim «Helvetyka», 2020. Vyp. 28. T. 2. S. 


\section{Питання психології}

181-187. URL: http://journals.uran.ua/index.php/2308-4855/article/view/208672 (data zvernennia 02.08.2020). DOI: https://doi.org/10.24919/2308-4863.2/28.208672

\section{Резюме \\ Хмиляр О. Ф. доктор психологических наук, профессор, начальник кафедры общественных наук Наџионального университета обороны Украины имени Ивана Черняховского \\ ФЕЙК - ИНФОРМАЦИОННЫЙ МАРКЕР И РЕГУЛЯТОР ПОВЕДЕНЧЕСКОЙ АКТИВНОСТИ ЛИЧНОСТИ ВОЕННОСЛУЖАЩЕГО}

Свободный доступ к получению информации, интенсивный и ииклический ее оборот привели к массовому распространению фейков, что усиливается широким использованием различных масс-медиа и особенно соииальных сетей. Статья призвана раскрыть роль фейковых сообщение в структуре поведенческой активности личности военнослужсащего, осветить семантическую конструкиию фейка для привлечения к нему внимания человеком, выляснить когнитивные предубежсения, что выступают инструментом убеждения в принятии ошибочного решения. Автором выделены условия, которые максимизируют влияние когнитивных предубеждений и побуждают военнослужащего поверить фейковому сообщению.

Ключевые слова: фейк; сообщение; действие; эффект; сочиальные медиа; когнитивные предубеждения; влияние.

\section{Summary \\ Khmiliar O. Doctor of Psychological Sciences, Professor, Head of the Department of Social Sciences, National Defense University of Ukraine named after Ivan Cherniakhovskyi \\ FAKE AS AN INFORMATION MARKER AND REGULATOR OF BEHAVIORAL ACTIVITY OF THE SERVICEMAN'S PERSONALITY}

Introduction. Free access to information, its intensive and cyclical circulation have led to the mass spread of fakes, which is intensified by the widespread use of various mass media, especially social networks. It is quite difficult to distinguish false (fake) information from the truth. Fake messages are designed to change the reality of the serviceman. Most of the fake messages, that are aimed at servicemen, are about war and politics and are based on references to "betrayals" and "victories".

Purpose. The article aims to reveal the role of fake messages in the structure of behavioral activity of a serviceman, highlight the semantic structure of the fake, designed to attract attention, and clarify the cognitive biases that serve as a tool to make wrong decisions.

Methods. To realize the purpose of the article, we proceed from the fact that the theoretical study of fakes, from a methodological point of view, belongs to the highest level of scientific knowledge, as it reveals and substantiates the deeper and more significant aspects of this phenomenon. We use the following general scientific methods: analysis, synthesis, induction, deduction, comparison, formalization, abstraction, modeling. The use of the historical method made it possible to comprehensively reveal the study of fakes in chronological order, establishing its inner essence, patterns of influence on the target audience and contradictions in the decoding of messages.

Originality. It has been proven that, in essence, a fake is a type of targeted information weapon used to covertly broadcast certain ideas or messages. The latter, in turn, are used to change the emotional and psychological attitudes of a particular target audience. It is shown that the spread of fake messages results in a state of mass cognitive dissonance in the representatives of the target group, against which this type of information weapon is used.

Conclusion. To systematize the path, that fake information undergoes to achieve the end result (to make people believe in it), it should be divided into three stages: 1) attracting attention; 2) beliefs; 3) decision making. The negative effects of fakes are primarily aimed at damaging the emotional, motivational, social, existential and intellectual side of the soldier's psyche. It has been established that a fake is a powerful information weapon of mass media, which on a subconscious level influences the behavioral regulation of human actions, and the individual does not always notice and realize this. Fakes can worsen physical and mental health, cause changes in mental processes, motivation, priorities and affect interaction in society. Knowledge of the specifics of the psychological impact of fakes on the individual will help understand the need to analyze information content, search, critically select and review messages to maintain own mental health.

Keywords: fake; message; action; effect; social media; cognitive bias; influence.

Recelved/Поступила: 21.06. 21. 